\title{
Vegetation Dynamics in the Northern Zones of Niger: Case of the Rural Commune of Tanout (Zinder) and Aderbissinat (Agadez)
}

\author{
Abdoul Kader Soumaila Sina, Nouhou Ali, Amadou Garba, and Bernard Minoungou
}

\section{ABSTRACT}

The present study conducted in the northern zone of Niger aims to show the impact of land use dynamics on woody vegetation. The methodological approach consisted in making in addition to the floristic surveys, the analysis of land use maps (LANDSAT images of the years 1975 and 2018). The floristic inventory allowed the identification of twenty-seven (27) woody species of which eleven (11) in Tanout and sixteen (16) in Aderbissinat. The most important families remain the FabaceaeMimosoideae which represent $37.5 \%$ at Aderbissinat and $45.45 \%$ at Tanout. The biological types remain dominated by microphanerophytes which dominate $(\mathbf{8 6 . 6 7 \%})$, while for the phytogeographic types it is the Sudano-Zambezian and Sudanian species that dominate, with proportions respectively equal to $31.25 \%$. There is a regression of woody vegetation at the level of these communes with a slight loss in Aderbissinat (60588,034 ha) and an accentuated degradation of vegetation in Tanout (781797,738 ha).

Keywords: Vegetation Dynamics, Sahel, Niger.

\section{INTRODUCTION AND ISSUES}

The Sahel is constantly undergoing changes in both land use and floristic recomposition. This degradation of ecosystems in developing countries is the second most worrying environmental issue of the 21 st century after climate change [1], [2]. While at the global level, forest losses for the period $2005-2010$ were $0.14 \%$ per year, West Africa stands out with an estimated deforestation rate of $0.46 \%$ [3]. The Sahelian zone, characterized by limited and vulnerable forest resources, saw an annual decline of $1.07 \%$ in forest cover over the same period [3]. The degradation of forest ecosystems, the economic lungs of rural populations, constitutes a major constraint for the sustainable development of developing countries.

In Niger, this environmental problem is presented in terms of the imbalance between, on the one hand, natural resources (soil, water, vegetation, fauna, etc.) and, on the other hand, the increased needs of a rapidly growing population $(3.9 \%$ /year) seeking to improve their living conditions. This situation is accelerating the degradation of forest formations at a worrying rate. Agriculture, wildfires, overgrazing, woodcutting and the search for non-timber
Published Online: February 10, 2021

ISSN: $2684-446 \mathrm{X}$

DOI :10.24018/ejgeo.2021.2.1.111

Abdoul Kader Soumaila Sina* Engineering and Design Office in Environmental Management (BEGEC International) (www.begec-int.com), Project DTS/FO, Niger.

(e-mail: aksoumailasina ${ }^{\circledR}$ gmail.com) Nouhou Ali

Abdou Moumouni Niamey University, Faculty of Letters and Human Sciences, Department of Geography, Research Laboratory Sahelo-Saharan Territories, Niger.

(e-mail: nouhougeo@yahoo.de)

Amadou Garba

Abdou Moumouni University of Niamey,

Faculty of Science and Technology, Department of Biology, GARBA Mounkaila Laboratory, Niger.

(e-mail: garbaamadou10@yahoo.fr) Bernard Minoungou

AGRHYMET Regional Center, Niger. (e-mail: minoungoubernard@yahoo.fr)

*Corresponding Author

forest products are the main factors in the degradation of plant formations in Niger's Sahelian ecosystems.

In the northern zone of Niger, the degradation of plant formations is characterized by the reconversion of agricultural ecosystems (e.g. agroforestry parks) into arid ecosystems unsuitable for agriculture. The deterioration of climatic conditions and anthropic activities are accentuating, resulting in increasingly harmful effects on the ecological and socio-economic levels.

\section{MATERIAL AND METHOD}

\section{A. Presentation of the Study Area}

\section{Urban Municipality of Tanout}

The Urban Commune of Tanout is located in the extreme North of the Region of Zinder and the Department of Tanout $\left(14^{\circ} 5\right.$ and $17^{\circ} 30$ North latitude and $7^{\circ} 20$ and $9^{\circ} 37$ East longitude). Its population is estimated at 128,531 inhabitants in 2008 [4]. It is bounded to the east by the rural commune of Tenhya, to the west by the rural commune of Gangara, to the north by the rural communes of Aderbissinatt (Agadez) and Tenhya, and to the south by the rural communes of Olléléoua, Alakoss (Gouré) and Kangna Wamé (Mirriah). It 
covers an area of $6,780 \mathrm{~km}^{2}$, i.e., $20.43 \%$ of the area of the Department of Tanout estimated at $33,171 \mathrm{~km}^{2}$ and $4.63 \%$ of the total area of the Region of Zinder estimated at $146,170 \mathrm{~km}^{2}$.

Geologically, it belongs to the southern part of the Iullemenden Basin. It is characterized by the following geological formations:

- the clay plateau of Damergou in the North;

- the sandstone plateau of Koutouss in the East;

- the crystalline basement of Damagaram-Mounio in the South;

- the alluvial deposits of the Tarka Valley in the West.

Its climate is sub-desert Sahelian. The seasons, temperatures, winds and precipitation are largely dependent on it. Two (2) types of winds are largely dominant in the Urban Commune of Tanout, namely harmattan and monsoon. The vegetation cover of the commune is mainly composed of Acacia and Prosopis. There are: Faidherbia albida, Acacia nilotica, Acacia séyal, Acacia Radiana, Balanites aegyptiaca, etc.

The large fauna is practically disappearing in the municipality to make way for a residual fauna composed of birds, rodents, reptiles and insects.

The dominant agricultural system is rain-fed agriculture, which is the main economic activity of the population. Livestock farming, due to the size of the commune's livestock population and the multitude of related economic activities, truly constitutes the second udder of the local economy. Tourism, transport, and handicrafts are also practiced in the commune.

\section{Rural community of Aderbissinat}

The rural commune of Aderbissinat is located in Niger, in the region of Agadez, department of Aderbissinat (LN 15'37"28; LE 007'53"32). It has a population of 35,320 inhabitants [5]. It covers an area of $25,000 \mathrm{~km}^{2}$ and is bounded to the south by the communes of Tanout, Tenhiya and Belbéji, to the north by the communes of Agadez and Tchirozérine, to the west by the communes of Tamaya and Ingall and finally to the east by the Rural Commune of Tabelot [4].

The commune is characterized by the cliffs of Tiguidit, the plains of the Irhazer, the plateaux of Tadress and northern Damergou and the Ergs of the Sahara.

The soils are sandy-silty in the dune areas, on the plateaux and plains, clayey-silt to clayey in the shallows and sandy at the level of temporary and semi-permanent pools and koris.

The climate of the area is of semi-arid Sahelo-Saharan type, hot and dry with temperatures exceeding $40{ }^{\circ} \mathrm{C}$ in the dry season. The prevailing wind is the Harmattan which blows from east to west almost all year round. Rainfall varies from 200 to $250 \mathrm{~mm} /$ year.

The woody shrub and tree resource is more concentrated around ponds and along the koris. The most frequently encountered plant species are the following: Panicum turgidum, Cenchrus biflorus, Dactylostenium aegyptium, Acacia ehrenbergiana, Acacia laeta, Boscia senegalensis, Acacia nilotica, Balanites aegyptiaca, Ziziphus mauritania, etc.

Wildlife resources include guinea fowl, hares, some bustards, ravens, partridges, etc.
The commune of Aderbissinat is classified as a pastoral zone, but irrigated crops are gradually gaining ground. Animal husbandry is practiced by most of the population of the rural commune of Aderbissinat (camels, cattle, sheep, goats, asins, horses, etc.). Vegetable and cereal crops are cultivated by producers around the water points. Several other socioeconomic activities are practiced in the commune including crafts, tourism and hospitality, trade, transport, etc.

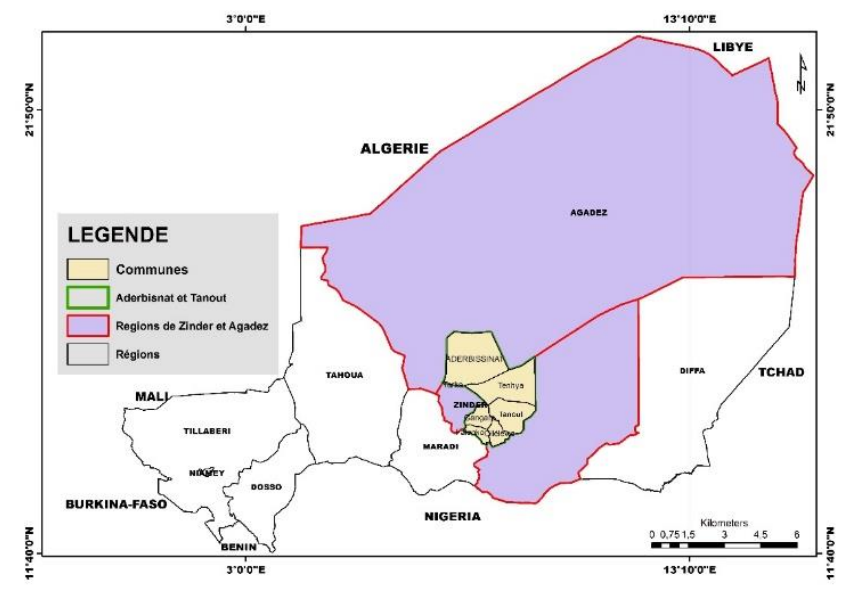

Fig 1. Location of the study area.

\section{B. Methodology}

Climatic data (rainfall and temperature) have made it possible to calculate the trend in rainfall and temperature over the last four decades.

\section{Sampling and dendrometric surveys}

The study of the vegetation in the area was conducted on the basis of a floristic inventory, carried out in sampling units (plots), arranged on transects several kilometers apart. These transects were oriented in an east-west and northsouth direction in order to better take into account the state of occupation of the forest and its diversity (Fig. 3). The dimensions of the sampling units are $2500 \mathrm{~m}^{2}$ in agrosystems $(50 \mathrm{~m} 50 \mathrm{~m})$ and $1000 \mathrm{~m}^{2}$ in fallow land $(20 \mathrm{~m}$ $50 \mathrm{~m}$ ). Within each sampling unit, all the woody species have been counted and the different dendrometric parameters recorded are:

- The height of the trees;

- The diameter at $20 \mathrm{~cm}$ from the ground for shrubs;

- The diameter at $1 \mathrm{~m} 30$ from the ground for the trees;

- The crown (average diameter);

- And the number of rejects that has been counted. In this study, is a reject, any subject or stem with a diameter less than or equal to two centimeters $(\mathrm{d} \leq 2 \mathrm{~cm})$;

- Data on stationary factors such as soil texture, terrain geomorphology, plot midpoint coordinates, type of land use were also collected.

\section{Phytosociological surveys}

In addition to the floristic surveys, phytosociological surveys were carried out following the methodological approach of brun blanc. This method of studying the vegetation consists in assigning to each species present in the inventory plot, a coefficient of abundance dominance. It allows to describe the plant communities and to understand the spatio-temporal organization on the quantitative and 
qualitative level of the constituent species. It has the advantage of drawing up the floristic list of the investigated area and of understanding the environmental conditions through the species. The Braun-Blanquet scale is as follows:

5: species covering more than $75 \%$ of the survey area, i.e. an average coverage (RM) of $87.5 \%$;

4: species covering between $50 \%$ and $75 \%$ of the survey area, i.e. a mean coverage (MR) of $62.5 \%$;

3: species covering between $25 \%$ and $50 \%$ of the survey area, i.e. a mean coverage (MR) of $37.5 \%$;

2: species covering between $5 \%$ and $25 \%$ of the survey area, i.e. a $\mathrm{RM}$ of $15 \%$;

1: species abundant to less abundant and covering less than $1 \%$ of the survey area, i.e. a RM of $3 \%$;

+ : rare species and covering less than $5 \%$ of the survey area, i.e. a RM of $0.5 \%$.

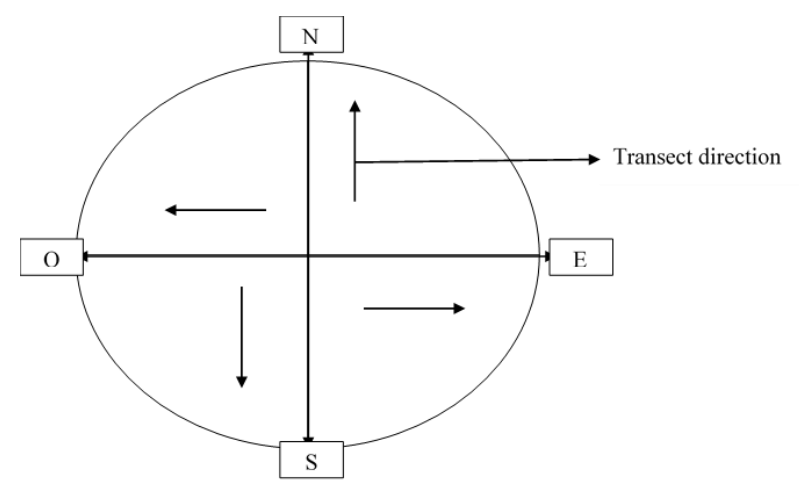

Fig 2. Vegetation sampling device.

\section{Satellite data}

The satellite images used are Landsat7 type images from 1975 and 2018. The spatial resolution of these images is 30 meters, UTM zone $31 \mathrm{~N}$ projection with WGS84 reference ellipsoid.

\section{Data processing and analysis}

\section{Description of plant groups}

Life forms (biological types)

They were defined by Raunkiar according to the position of the buds and the size of the individuals [6]. The determination of the forms of plant adaptations ensures a better appreciation of the ecological conditions in which they evolve [7].These biological types, by their distribution, faithfully reflect the ecological conditions of a region and their study gives an idea of the vegetation of a given area [8]. In this work, the classification of [6] for the study of intertropical plant formations according to [9]; [10] has been adopted. It consists of:

$>$ Therrophytes (The): annual plants whose perenniality is ensured by seeds or spores.

$>$ Hemicryptophytes $(\mathrm{H})$ : perennial plants whose survival buds are protected by the soil. The aerial apparatus is herbaceous and disappears for the most part at the threshold of the bad season.

$>$ Geophytes $(\mathrm{Ge})$ : plants with a very fragile aerial apparatus and perennial organs hidden in the earth (geophytes). Geophytes are subdivided according to the type of organ into: rhizomatous geophytes (Gr), bulbous geophytes $(\mathrm{Gb})$ and tuberous geophytes $(\mathrm{Gt})$.
They resume normal life as soon as the rainy season starts again.

$>$ Hygrophytes (Hy): plants with a very fragile aerial apparatus and perennial organs hidden in wet mud or even water. This form of protection is very effective against drought and wide temperature variations.

$>$ Chamephytes (Ch): subligneous or herbaceous plants that cross the season with a stem that is not very evolved above the ground. Most of the aerial part disappears during the dry season and the recovery takes place with the resettlement of the rainy season.

$>$ Phanerophytes $(\mathrm{Ph})$ : perennial plants, represented by trees, shrubs, lianas and woody shrubs, whose hibernating buds are carried high and thus exposed to the weather. In Niger, this group is subdivided into:

$>$ Nanophanerophytes (NnPh), 0.5 to 2 m high;

$>$ Microphanerophytes $(\mathrm{McPh}), 2$ to $8 \mathrm{~m}$ high;

$>$ Mesophanerophytes (MsPh), 8 to $30 \mathrm{~m}$ high;

$>$ Megaphanerophytes $(\mathrm{MPh})$, greater than $30 \mathrm{~m}$ in height.

Spectrum of phytogeographic types

Phytogeographic types provide information on the origin and range of the different species in the plant groupings. The distribution of phytogeographic types has been established in accordance with the accepted chorological subdivisions for Africa [11]. They are:

- Broadly distributed species:

$>$ Cosmopolitan (Cos): species distributed in tropical and temperate regions of the world;

$>$ African-American (AA): species widespread in Africa and America;

$>$ Pantropical (Pan): species widespread in Africa, America and tropical Asia;

$>$ Paleotropical (Pal): species distributed in tropical Africa, tropical Asia, Madagascar and Australia.

- Species with limited distribution on the African continent

$>$ Tropical Afro-Malagasy (AM): species distributed in Africa and Madagascar;

$>$ Afro-Tropical (AT): species widespread in tropical Africa;

> Pluri-regional (PA): species whose range extends to several regional centers of endemism;

> Sudano-Zambezian (SZ): species distributed in both the Sudanian and Zambezian regional centers of endemism;

$>$ Guineo-Congolese (GC): species distributed in the Guinean region.

- Base element

Sudanian (S): species widely distributed in the regional center of the Sudanese endemism.

\section{Satellite Images}

The image processing was carried out following several geometrical and radiometric corrections. Bands 5; 4 and 3 were used for the color composition because they better characterize the vegetation cover. The classification, supervised by the maximum likelihood algorithm, was used on the basis of the acquired terrain recognition.

The results of the verification test give the confusion matrices that compare the cartographic results with the data 
collected in the field. Overall accuracy is measured by the Kappa coefficient [12]-[15]. The Arc Map 10.5 software was used for image analysis.

\section{RESULTS}

\section{A. Climatic Evolution}

The average temperature from 1985 to 2019 is $27.3^{\circ}$ with an annual evolution of $0.008{ }^{\circ} \mathrm{C}$. The trend in the evolution of precipitation since 1985 is relatively increasing. A series of surplus years is observed from 1997 onwards.

The average rainfall of the 1985-2019 series of Aderbissinat is $92.5 \mathrm{~mm}$. In terms of climatic evolution, the two study communes have the same characteristics.

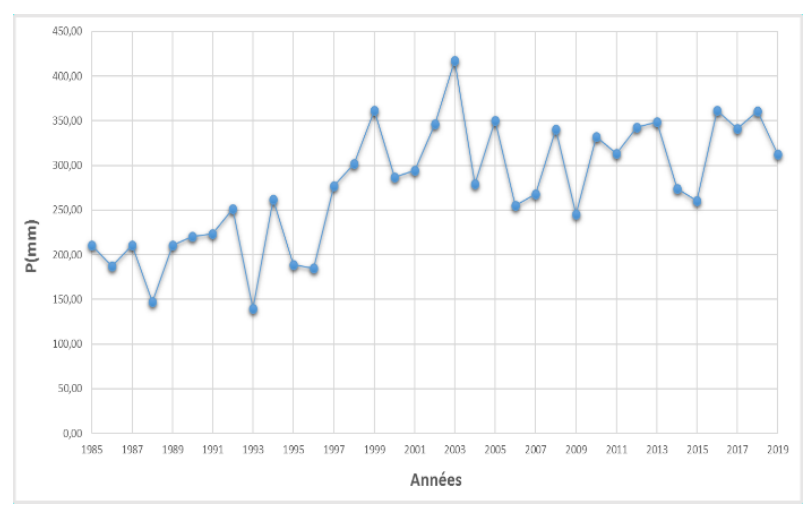

Fig 3. Evolution of rainfall in Aderbissinat.

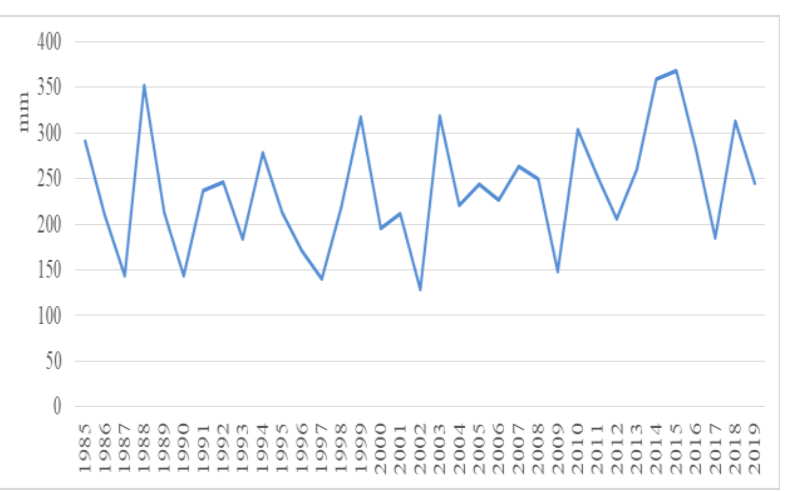

Fig 4. Evolution of rainfall in Tanout. Source: Agrhymet 2020.

\section{B. Evolution of Vegetation Cove}

As observed in the field, the results of the occupancy maps show a regressive trend in the area of vegetation cover in both zones (Table 2). This regressive trend is characterized by an unprecedented degradation of woody vegetation (Fig. 5). Indeed, over a period of forty-three years (43 years) the loss of vegetation cover amounts to $20.16 \%$ in Tanout and $10.27 \%$ in Aderbissinat).

TABLE 1: AREAS OF OCCUPATION OF WOODY VEGETATION IN THE YEARS

\begin{tabular}{cccc}
\multicolumn{4}{c}{1975 AND 2018 } \\
\hline Communes & Year & $\begin{array}{c}\text { Superficies } \\
\text { (ha) }\end{array}$ & $\begin{array}{c}\text { Lost superficies } \\
\text { (ha) }\end{array}$ \\
\hline Tanout & 1975 & 1004466,62 & 781797,738 \\
\multirow{2}{*}{ Aderbissinat } & 2018 & 222668,88 & \\
& 1975 & 589924,874 & 60588,034 \\
\hline
\end{tabular}

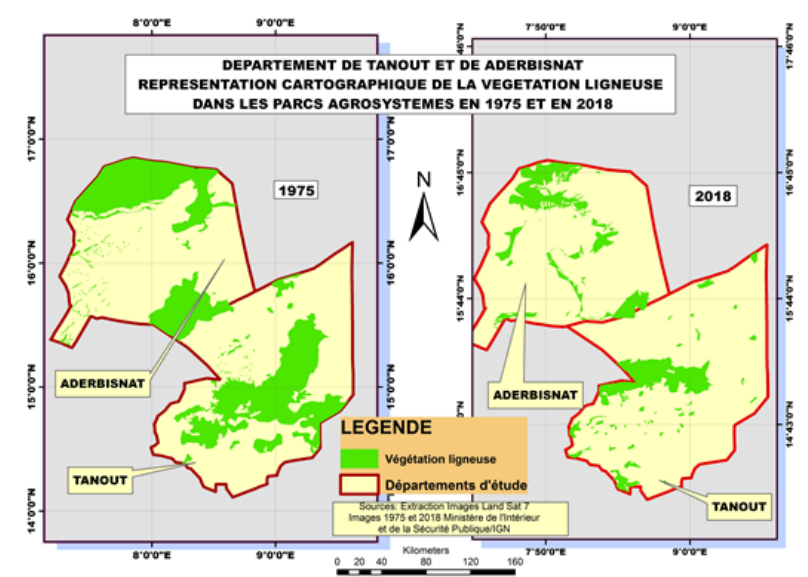

Fig. 5. Mapping of the occupation of woody vegetation from 1975 and 2018 in Tanout and Aderbissinat.

\section{Floral Composition}

The floristic inventory of the vegetation made it possible to identify a total of twenty-seven (27) woody species distributed between the commune of Tanout and Aderbissinat.

\section{Commune of Tanout}

Eleven (11) woody species were recorded in the rural commune of Tanout (Table 1), divided into 7 families, the most important of which are the Fabaceae-Mimosoideae $(45.45 \%)$. The other no less important families are Anacardiaceae, Asclepiadaceae, Balanitaceae, Caparaceae, Combretaceae and Rhamnaceae, with $9.09 \%$ each.

TABLE 2: FLORISTIC LIST OF WOODY SPECIES RECORDED IN THE COMMUNE OF TANOUT

\begin{tabular}{|c|c|c|c|c|c|}
\hline Species & TB & $\mathrm{TP}$ & Families & Number & $\begin{array}{c}\text { Frequencies } \\
(\%)\end{array}$ \\
\hline $\begin{array}{l}\text { Acacia } \\
\text { nilotica }\end{array}$ & $\mathrm{McPh}$ & $S$ & $\begin{array}{c}\text { Fabaceae- } \\
\text { Mimosoideae }\end{array}$ & 1 & 9,09 \\
\hline $\begin{array}{l}\text { Acacia } \\
\text { radiana }\end{array}$ & $\mathrm{McPh}$ & S & $\begin{array}{l}\text { Fabaceae- } \\
\text { Mimosoideae }\end{array}$ & 1 & 9,09 \\
\hline $\begin{array}{l}\text { Acacia } \\
\text { senegal }\end{array}$ & $\mathrm{McPh}$ & Pal & $\begin{array}{l}\text { Fabaceae- } \\
\text { Mimosoideae }\end{array}$ & 1 & 9,09 \\
\hline $\begin{array}{c}\text { Balanites } \\
\text { aegyptiaca }\end{array}$ & $\mathrm{McPh}$ & $\mathrm{SZ}$ & Balanitaceae & 1 & 9,09 \\
\hline $\begin{array}{c}\text { Boscia } \\
\text { senegalensis }\end{array}$ & $\mathrm{McPh}$ & $S$ & Caparaceae & 1 & 9,09 \\
\hline $\begin{array}{l}\text { Faiderbia } \\
\text { albida }\end{array}$ & $\mathrm{McPh}$ & $\mathrm{PA}$ & $\begin{array}{c}\text { Fabaceae- } \\
\text { Mimosoideae }\end{array}$ & 1 & 9,09 \\
\hline $\begin{array}{c}\text { Guiera } \\
\text { senegalensis }\end{array}$ & $\mathrm{NnPh}$ & $\mathrm{SZ}$ & Combretaceae & 1 & 9,09 \\
\hline $\begin{array}{l}\text { Leptadenia } \\
\text { pyrotechnica }\end{array}$ & $\mathrm{McPh}$ & $\mathrm{SZ}$ & Asclepiadaceae & 1 & 9,09 \\
\hline $\begin{array}{l}\text { Prosopis } \\
\text { juloflora }\end{array}$ & $\mathrm{McPh}$ & $\mathrm{i}$ & $\begin{array}{c}\text { Fabaceae- } \\
\text { Mimosoideae }\end{array}$ & 1 & 9,09 \\
\hline $\begin{array}{c}\text { Sclerocaria } \\
\text { birrea }\end{array}$ & $\mathrm{MsPh}$ & S & Anacardiacea & 1 & 9,09 \\
\hline $\begin{array}{c}\text { Ziziphus } \\
\text { mauritiana }\end{array}$ & $\mathrm{McPh}$ & Pal & Rhamnaceae & 1 & 9,09 \\
\hline Total = 11 & & & & 11 & 100,00 \\
\hline
\end{tabular}

\section{Commune of Aderbissinat}

In this municipality, 16 woody species have been inventoried (Table 2), which are divided into 10 families, the most important of which are the Fabaceae-Mimosoideae $(37.5 \%)$. The other no less important families represent each $6.25 \%$ respectively. 
TABLE 3: FLORISTIC LIST OF WOODY SPECIES RECORDED IN THE COMMUNE OF ADERBISSINAT

\begin{tabular}{|c|c|c|c|c|c|}
\hline Species & TB & $\mathrm{TP}$ & Families & Number & $\begin{array}{c}\text { Frequencies } \\
(\%)\end{array}$ \\
\hline $\begin{array}{c}\text { Acacia } \\
\text { ehrenbergiana }\end{array}$ & $\mathrm{McPh}$ & SZ & $\begin{array}{c}\text { Fabaceae- } \\
\text { Mimosoideae }\end{array}$ & 1 & 6,25 \\
\hline Acacia laeta & $\mathrm{McPh}$ & PA & $\begin{array}{c}\text { Fabaceae- } \\
\text { Mimosoideae }\end{array}$ & 1 & 6,25 \\
\hline Acacia nilotica & $\mathrm{McPh}$ & S & $\begin{array}{c}\text { Fabaceae- } \\
\text { Mimosoideae }\end{array}$ & 1 & 6,25 \\
\hline Acacia radiana & $\mathrm{McPh}$ & $\mathrm{S}$ & $\begin{array}{c}\text { Fabaceae- } \\
\text { Mimosoideae }\end{array}$ & 1 & 6,25 \\
\hline $\begin{array}{l}\text { Balanites } \\
\text { aegyptiaca }\end{array}$ & $\mathrm{McPh}$ & Pal & Balanitaceae & 1 & 6,25 \\
\hline $\begin{array}{c}\text { Boscia } \\
\text { senegalensis }\end{array}$ & $\mathrm{McPh}$ & $\mathrm{SZ}$ & Capparidaceae & 1 & 6,25 \\
\hline $\begin{array}{l}\text { Calotropis } \\
\text { procera }\end{array}$ & $\mathrm{McPh}$ & $\mathrm{Pal}$ & Asclepiadacea & 1 & 6,25 \\
\hline $\begin{array}{l}\text { Commiphora } \\
\text { africana }\end{array}$ & $\mathrm{McPh}$ & SZ & Burseraceae & 1 & 6,25 \\
\hline Cordia sinensis & $\mathrm{nP}$ & $\mathrm{SZ}$ & Boraginaceae & 1 & 6,25 \\
\hline $\begin{array}{l}\text { Euphorbia } \\
\text { balsamifera }\end{array}$ & $\mathrm{McPh}$ & Cos & Euphorbiacea & 1 & 6,25 \\
\hline $\begin{array}{l}\text { Faidherbia } \\
\text { albida }\end{array}$ & $\mathrm{McPh}$ & PA & $\begin{array}{c}\text { Fabaceae- } \\
\text { Mimosoideae }\end{array}$ & 1 & 6,25 \\
\hline $\begin{array}{l}\text { Leptadenia } \\
\text { pyrotechnica }\end{array}$ & $\mathrm{McPh}$ & SZ & Asclepiadacea & 1 & 6,25 \\
\hline $\begin{array}{l}\text { Maerua } \\
\text { crassifolia }\end{array}$ & $\mathrm{McPh}$ & $\mathrm{SZ}$ & Capparaceae & 1 & 6,25 \\
\hline $\begin{array}{l}\text { Prosopis } \\
\text { juloflora }\end{array}$ & $\mathrm{McPh}$ & $\mathrm{i}$ & $\begin{array}{c}\text { Fabaceae- } \\
\text { Mimosoideae }\end{array}$ & 1 & 6,25 \\
\hline $\begin{array}{l}\text { Sclerocaria } \\
\text { birrea }\end{array}$ & $\mathrm{MsPh}$ & $\mathrm{S}$ & Anacardiaceae & 1 & 6,25 \\
\hline $\begin{array}{c}\text { Ziziphus } \\
\text { mauritiana }\end{array}$ & $\mathrm{McPh}$ & $\mathrm{Pal}$ & Rhamnaceae & 1 & 6,25 \\
\hline Total $=16$ & & & 16 & 16 & 100 \\
\hline
\end{tabular}

D. Description of the Biological and Phytogeographic Types of Plants

\section{The biological types}

The results in Fig. 6 show the proportions of the biological forms of the woody species inventoried in the area. Analysis of these results shows that microphanerophytes dominate $(86.67 \%)$ followed by mesophanerophytes and nanophanerophytes in proportions respectively equal to $6.66 \%$.

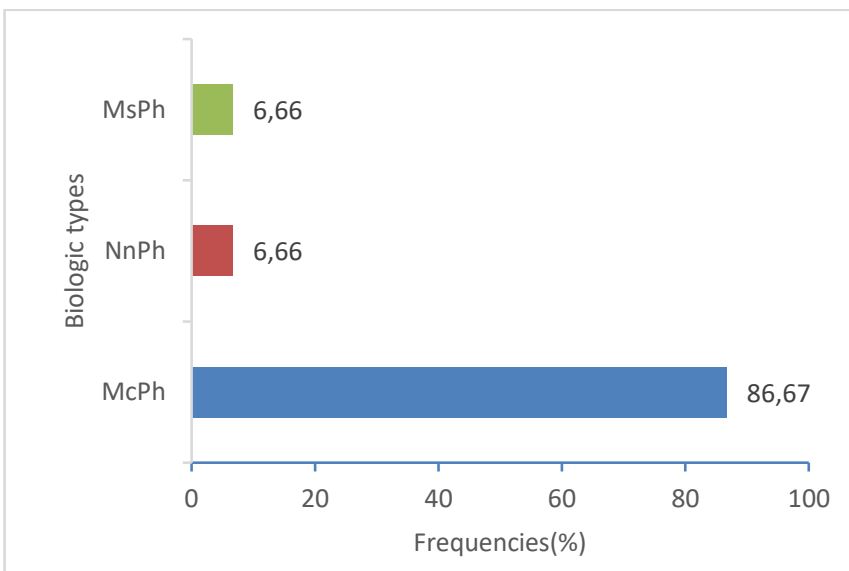

Fig 6. Proportions of biological types.

$\mathrm{McPh}=$ microphanérophytes; $\mathrm{MsPh}=$ mésophanérophytes; $\mathrm{NnPh}=$ nanophanérophytes.

\section{Phytogeographical types}

The results in Fig. 7 illustrate the proportions of phytogeographic types. These results show that the SudanoZambezian and Sudanian species dominate, with proportions respectively equal to $31.25 \%$, followed by species of paleotropical type $(18.75 \%)$. These are followed by species of multi-regional, introduced, and cosmopolitan type in proportions respectively equal to $6.25 \%$.

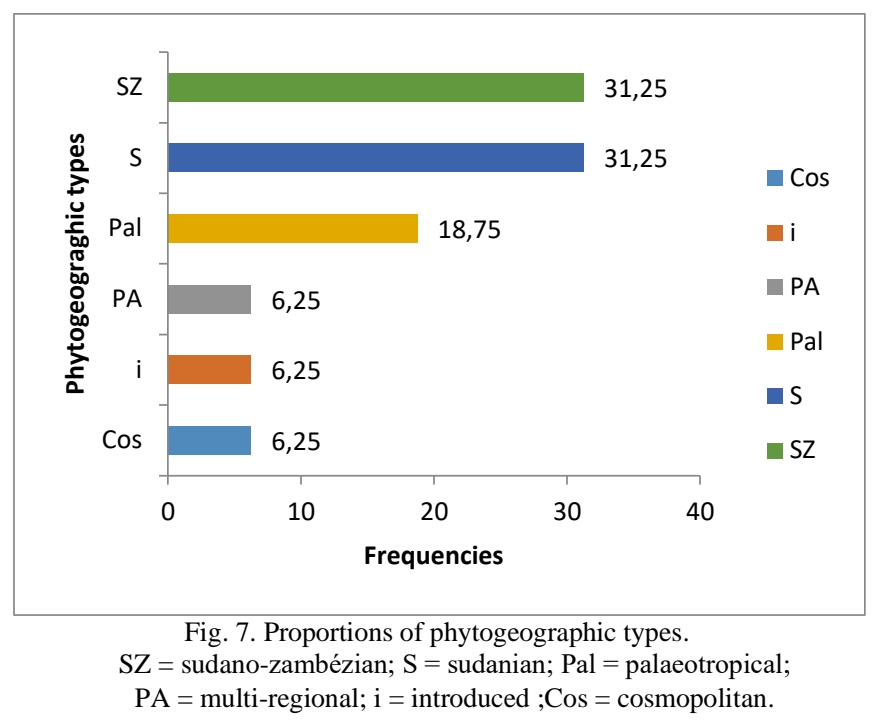

\section{Scheduling of statements}

The dominance abundance matrix of the phytosociological surveys was subjected to a correspondence factor analysis. This allowed the similarity threshold of $62.5 \%$ to obtain four (04) plant groupings (Fig. 8). Grouping G1 composed of eight (08) species, grouping G 2 composed of two (02) species, grouping G 3 composed of five (05) species and grouping $\mathrm{G} 4$ composed of only one (01) species.

\section{E. Dendrometric Parameters}

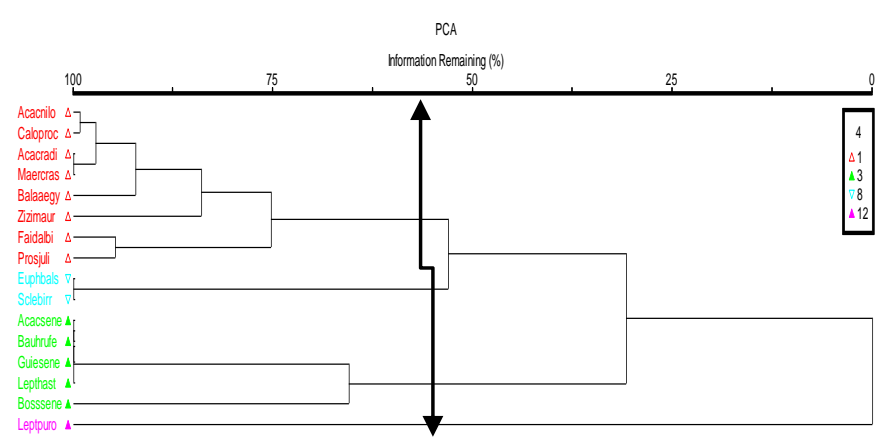

Fig. 8. Dendrogram of plant groupings.

\section{DISCUSSION}

Since climatic fluctuations influenced mainly by rainfall are insignificant, the dynamics of vegetation lies in anthropogenic pressure. The armed insurrections of the 1990s and the residual banditry since the destabilization of Libya in 2011 have led to a concentration of herds in the southern Air Mountains where the plains abound in relatively abundant pasture. Also, before the great drought of 1973, most transhumance was oriented towards the north, where the pastoral zone is located [16]. This phenomenon contributed to overexploitation of the wood resource (Fig. 5 ), with a loss of vegetation cover of $20.16 \%$ in Tanout and $10.27 \%$ in Aderbissinat over a period of 43 years. This 
situation is present in several West African countries [17][19].

\section{A. Floristic Characteristics of the Area}

The flora richness, which reflects the structure and functioning of plant communities, is the biological indicator most often used to assess the state of an ecosystem. State that any increase in floristic richness can be the cause of a process of self-restoration of a degraded ecosystem [20]. The results on species richness in this study are significantly lower than those obtained by [21] in the natural and postcultural formations of the classified forests of Dan Kada Dodo-Dan Gado. These prove that the ecosystems of the northern zone of Niger are highly degraded. The low floristic composition of the zone testifies to the strong presence of anthropic factors which significantly disturb the functioning of these ecosystems. They constitute, therefore, the main factors that lead to a modification in the floristic composition and structure of vegetation [22]. The woody flora of these sites remains dominated by FabaceaeMimosoideae and Combretaceae. Individuals from these two families now colonize Sahelo-Sudanian ecosystems through several mechanisms of dissemination (zoochory, anthropochory and anemochory). The two families mentioned above are indicative of a generally dry and arid climate [23].

The analysis of the biological types gives an idea of the dynamics of a phytocenosis [24]. The predominance of microphanerophytes in the Sahelian zone has also been noted by several authors [25], [26]. It results from these observations that the privileged position of these plant families is based on an optimal composition strategy including longevity, large size and ecological tolerance [27]. The phytogeographic type remains dominated by SudanoZambezian (SZ) species. They constitute a biological indicator that provides information on the dynamism or stability of plant communities [28]. These results thus obtained corroborate those of several authors [14].

In Niger and in the rest of the world, rainfall recession has been observed [29]-[31], with deficits since the 1970s and 1990s and changes in agro-ecological zones in West Africa [32]. In the north (Aderbissinat and Tanout) of Niger, as shown in Figure 3, the evolution of rainfall between 1975 and 2018 remained relatively constant with wet years recording more than $80 \mathrm{~mm}(1990,1993,1997)$. In all cases, annual rainfall remains globally below $60 \mathrm{~mm}$ per year. The climatic fluctuation with the average temperature from 1985 to 2019 which is $27.3{ }^{\circ} \mathrm{C}$, an annual evolution of $0.008{ }^{\circ} \mathrm{C}$ and the rainfall trend mentioned above allow us to conclude that the dynamics of the vegetation cover lies in the anthropic pressure in view of the climatic fluctuations influenced mainly by rainfall which is insignificant. This corroborates the results of several authors who have worked on vegetation dynamics [26]. Numerous dead plants were recorded, the species most concerned being the families Fabaceae-Mimosoideae followed by Balanitaceae. This mortality is due to anthropogenic causes and to the effects of aridity in the study area, reducing the availability of useful water and nutrients and limiting the physiological functioning of plants [33]-[35].

\section{CONCLUSION}

The establishment of the diachronic map (1975-2018) of land occupation in the northern areas of Tanout and Aderbissinat, allowed us to show the dynamics of continuous degradation of the vegetation cover. This pastoral area is nowadays completely colonized by herbaceous and woody species not relished by animals and which are indicators of the protrusion of the desert front. The contribution of this study lies in highlighting changes in use of land, thus showing the need to set up a more efficient management system of the natural resources in the area for the well-being of the population of the area.

\section{REFERENCES}

[1] N'da, D., et al., Analyse de la diversité floristique du parc national de la Marahoué, Centre-Ouest de la Côte d'Ivoire. Afrique Science: Revue Internationale des Sciences et Technologie, 2008. 4(3).

[2] Hountondji, Y.-C.H., Dynamique environnementale en zones sahélienne et soudanienne de l'Afrique de l'Ouest: Analyse des modifications et évaluation de la dégradation du couvert végétal. Belgique: Université de Liège, 2008.

[3] FAO, Evaluation des ressources forestières mondiales 2010. Rapport principal. Etude FAO. Forêts n ${ }^{\circ} 163$, Rome, Italie, 2010: p. 348 p.

[4] PDC, Plan de développement communautaire de la commune rurale de Guéchémé. 2014. p. 119P.

[5] RGP, Recensement Général de la Population et de l'Habitat, 4ème Série. 2012.

[6] Raunkiaer, C., The life forms of plants and statistical plant geography; being the collected papers of C. Raunkiaer. The life forms of plants and statistical plant geography; being the collected papers of $\mathrm{C}$. Raunkiaer., 1934.

[7] Koechlin, Y. and A. Pascal, The speed of response of the 56 AVP photomultiplier and its measurement in the laboratory. 1961, Centre d'Etudes Nucleaires, Saclay, France.

[8] Mahamane, L. and S. Mahamane, Biodiversity of ligneous species in semi-arid to arid zones of southwestern Niger according to anthropogenic and natural factors. Agriculture, ecosystems \& environment, 2005. 105(1-2): p. 267-271.

[9] Natta, A., B. Sinsin, and L. Van Der Maesen, A phytosociological study of riparian forests in Benin (West Africa). Belgian Journal of Botany, 2003: p. 109-128.

[10] Rohlf, F.J. and G.D. Schnell, An investigation of the isolation-bydistance model. The American Naturalist, 1971. 105(944): p. 295324.

[11] White, J.G., et al., The structure of the nervous system of the nematode Caenorhabditis elegans. Philos Trans R Soc Lond B Biol Sci, 1986. 314(1165): p. 1-340.

[12] Perrenoud, P., Mobiliser ses acquis: où et quand cela s' apprend-il en formation initiale? De qui est-ce l'affaire? Recherche \& formation, 2000. 35(1): p. 9-23.

[13] Sissako, A., et al., Bamako. 2007: Trigon-film.

[14] Inoussa, M.M., et al., Dynamique spatio-temporelle des forêts claires dans le Parc national du W du Niger (Afrique de l'Ouest). Science et changements planétaires/Sécheresse, 2011. 22(2): p. 108-116.

[15] Young, R.M., et al., Identification of human semiochemicals attractive to the major vectors of onchocerciasis. PLoS Negl Trop Dis, 2015. 9(1): p. e3450.

[16] Bassett, T.J., C. Blanc-Pamard, and J. Boutrais, Constructing locality: The terroir approach in West Africa. Africa, 2007: p. 104-129.

[17] Bodart, C., et al., Contribution of SAR interferometry (from ERS1/2) in the study of aeolian transport processes: the cases of Niger, Mauritania and Morocco, in Desertification and risk analysis using high and medium resolution satellite data. 2009, Springer. p. 129-136.

[18] Bodart, C., A. Ozer, and D. Derauw, Suivi de l'activité des dunes au Niger au moyen de la cohérence interférométrique ERS $1 / 2$. Bulletin de la Société Géographique de Liège, 2010. 54(1): p. 123-136.

[19] Hountondji, Y.-C., et al., Ongoing desertification processes in the Sahelian belt of West Africa: an evidence from the rain-use efficiency. Recent advances in remote sensing and geoinformation processing for land degradation assessment. London: Taylor Francis Group, 2009: p. 173-186.

[20] Kallali, H., et al., GIS-based multi-criteria analysis for potential wastewater aquifer recharge sites. Desalination, 2007. 215(1-3): p. 111-119. 
[21] Abdourhamane, H., et al., Potential germination and initial growth of Sclerocarya birrea (A. Rich.) Hochst, in Niger. Journal of Applied Biosciences, 2014. 76: p. 6433-6443.

[22] Yorou, S., et al., Diversité et productivité des champignons comestibles de la forêt classée de Wari-Maro (Bénin, Afrique de l'Ouest). Systematics and Geography of Plants, 2001: p. 613-625.

[23] Mbayngone, E., et al., Magnoliophyta of the partial faunal reserve of Pama, Burkina Faso. Check List, 2008. 4: p. 251.

[24] Babatounde, S., et al., Valeur alimentaire des fourrages consommés par les taurillons Borgou sur les parcours naturels du centre du Bénin. International Journal of Biological and Chemical Sciences, 2011. 5(6): p. 2382-2394

[25] Mahamane, A., Usages des terres et évolutions végétales dans le département de Maradi. Vol. 27. 2001: Drylands Research Crewkerne, UK.

[26] Mahamane, A., S. Mahamane, and J. Lejoly, Phénologie de quelques espèces ligneuses du parc national $\mathrm{du}$ «W» du Niger. Sécheresse, 2007. 18(4): p. 354-358.

[27] Grime, J.P., Evidence for the existence of three primary strategies in plants and its relevance to ecological and evolutionary theory. The american naturalist, 1977. 111(982): p. 1169-1194.

[28] Sinsin, A.B., Phytosociologie, écologie, valeur pastorale, production et capacité de charge des pâturages naturels du périmètre NikkiKalalé au Nord-Bénin. 1993.

[29] Briquet, J., et al., Changements climatiques récents et modification du régime hydrologique du fleuve Niger Koulikoro (Mali). IAHS PUBLICATION, 1996: p. 157-166.

[30] Kouassi, C.K., et al., Profiles of bioactive compounds of some pepper fruit (Capsicum L.) varieties grown in Cote d'Ivoire. Innovative Romanian Food Biotechnology, 2012. 11: p. 23.

[31] Mena, M.S., et al., Les Changements Climatiques A Travers La Modification Du Régime Pluviométrique Dans La Région De Kribi (1935-2006). Rev. Ivoir. Sci. Technol, 2016. 28: p. 389-407.

[32] Diouf, D. and O. Boiral, The quality of sustainability reports and impression management. Accounting, Auditing \& Accountability Journal, 2017.

[33] FAO, Amenagement des forets naturelles des zones tropicales seches. No 32. Rome : FAO., 1997.

[34] Adjonou, K., R. Bellefontaine, and K. Kokou, Les forêts claires du Parc national Oti-Kéran au Nord-Togo: structure, dynamique et impacts des modifications climatiques récentes. Sécheresse, 2009. 20(1): p. $1-10$.

[35] Diallo, M.S., N.A. Fromer, and M.S. Jhon, Nanotechnology for sustainable development: retrospective and outlook, in Nanotechnology for Sustainable Development. 2013, Springer. p. 116.

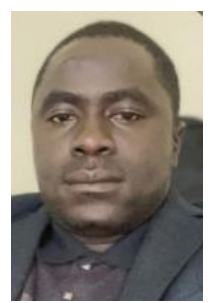

Sina Abdoul Kader Soumaila, PhD Student at the Doctoral School of Abdou Mounmouni University, Holder of a Master2 in Natural Resources Management and Biodiversity of the University of Abomey Calavi at the Laboratory of Applied Ecology of the Faculty of Agronomy, promoter of the Office of Studies in Environmental Management and Cartography (BEGEC International). It should be noted that SINA is the Environmental and Social Expert of the Trans-Saharan Fiber Optic Backbone Project (DTS Niger/African Development Bank (BAD) funding) and as such is in charge of safeguarding the project in its activities. To have carried out several environmental studies for projects (financed by the World Bank) and national and international private promoters.

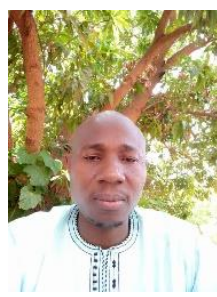

Garba Amadou, Water and Forestry Engineer Assistant to the Biophysical Observations and Cartography Division (D.O.B./C) at the National Center for Ecological and Environmental Monitoring (C.N.S.E.E.). PhD student in plant biology and ecology at the doctoral school of life and earth sciences (S.V.T) of the Abdou Moumouni University of Niamey.

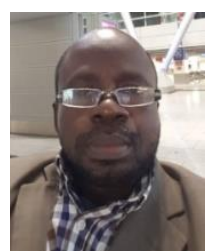

Nouhou Ali, PhD, Lecturer and researcher at the Abdou Moumouni University of Niamey in the Department of Geography, Research Laboratory Sahelo-Saharan Territories. Specialized in the teaching of climatology and problems related to climate change.

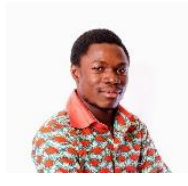

Minoungou Bernard, hydrologist at the regional agrhymet center.

His role is to carry out data analysis and hydrological modelling to define and quantify the dominant hydrometeorological processes in the main river basins of West Africa in order to implement tools for hydrological forecasting, information production on water resources, climate change and early warning. Part of his work is to collect better quality hydroclimatic data, to improve climate products, to contribute to building the capacities of the staff of the West African national hydrology and meteorology services. 